\title{
The Paris Climate Change Agreement: Where Does Africa Fit
}

\author{
in? \\ Theodore Okonkwo ${ }^{1 *}$ \\ ${ }^{1}$ Department of Public Law, Faculty of Law, University of Port-Harcourt, Port-Harcourt, Nigeria \\ *Theodore Okonkwo, E-mail: t161962@gmail.com
}

Received: April 12, 2017

Accepted: April 25, 2017

Online Published: May 10, 2017

doi:10.22158/se.v2n2p192

URL: http://dx.doi.org/10.22158/se.v2n2p192

\begin{abstract}
The 195 member state parties to the United Nations Framework Convention on Climate Change (UNFCCC) on December 2015 formally adopted the Paris Agreement on Climate Change. On April 22, 2016 not less than 175 world leaders converged on the United Nations Secretariat in New York and signed the Paris Agreement on Climate Change and 15 nations ratified it. As of March 1, 2017133 countries have joined the Paris Agreement. The Paris Agreement on Climate Change is absolutely critical for Africa, a continent that is susceptible to the influence of climate change. The Paris Agreement on climate change is expected to assist the African continent obtain financial aid and cutting-edge technology to alleviate the impact of climate change. This article examines the Paris Climate Change Agreement in the context of its significance for Africa and asks whether the climate change deal is a worthwhile pact from an African standpoint or just an agreement relating to approaches that are standard and not tailored to the African peculiar needs, in other words, "one size fits all”.
\end{abstract}

\section{Keywords}

Climate change, Paris Agreement, Africa, UNFCCC, impact, environmental, Kyoto Protocol, MDG, NEPAD, UNEP

\section{Introduction}

Lumumba Di-Aping, polemicall

y stated that, "You cannot ask Africa to sign a suicide pact, an incineration pact in order to maintain the economic dominance of a few countries". This statement was made in 2009 expressing disillusionment on the failed Copenhagen Accord. The Copenhagen conference experienced "deep splits amongst African delegates", while majority of African delegates "agreed with Di-Aping that it produced a disastrous outcome for the continent". In this regard, the Paris Climate Change Agreement has come to replace the failed Copenhagen Accord. Chin-Yee had argued that during the negotiation stage of the 
Paris Climate Change Agreement, "frustration" was very noticeable among African countries. According to him, "the newly condensed text came under heavy criticism from African Countries and the G77 (a coalition of 134 developing countries)".

The way and manner in which Africa understands climate change has been influenced by the deteriorating environment within the continent, thus, climate change has become a regional concern. Africa is part of the international comity of nations and continents "experiencing considerable economic, social and environmental challenges". One of the most environmental challenges is climate change which has threatened to thwart the socio-economic development of the continent. Climate change is adversely affecting the "future growth and development" of Africa, and the continent "cannot shy away from addressing its causes and impacts" despite being a developing continent.

Climate change has become an issue of not only global challenge but Africa's albatross, thus, the need for countries in Africa to make concerted efforts to mitigate the causes, and this they can do by instituting a holistic institutional, regional and national governance that will articulate policies in order to reduce greenhouse gas emissions that threaten the environment. With the adoption of the Paris Climate Change Agreement on December 2015, the United Nations based Green Climate Fund (GCF) is required to assist Africa "as a major ... climate finance instrument in helping the developing countries fulfill their commitments under the Paris Climate Change Agreement". Africa must rally round its component nation states to urgently, put in place national policies and institutions that will implement the content and goals of the Paris Climate Change Agreement "for essential development and climate action on the continent".

The goal of this article is to examine the threats and opportunities presented by climate change and how the Paris Climate Change Agreement could help Africa address the "issues related to governance of the global problem". This article argues that because of the regional adverse effects of climate change, countries in Africa nay the continent must map out policies and strategies to tackle what appears to threaten the future growth and development of the continent. This article examines the Paris Climate Change Agreement deal. It then briefly discusses its implementation globally and then hits the bull's eyes by examining the place of Africa in the whole deal and determines whether the Paris Climate Change Agreement deal is fit for Africa or is it "one size fits all". In conclusion, this article reflects on the challenges that African states face in trying to balance the demands of "climate action and sustainable development". Notwithstanding its shortcomings, this article argues that the Paris Climate Change Agreement remain the most viable international platform for Africa to realize its dream of economic and social development that meets the needs of future generations.

\section{The Paris Climate Deal}

The Paris Climate Change Agreement was adopted on December 12, 2015 during the 21st Conference of the Parties to the United Nations Framework Convention on Climate Change (UNFCCC). The Paris Climate Change Agreement provides a framework for global concerted actions to tackle climate change. 
The goal of the Agreement is to keep the rising global temperatures below 2 degrees Celsius "above pre-industrial levels" with the hope of limiting it to 1.5 degrees. It further aims to reinforce the capacity of nations to deal with the effects of climate change. To attain these lofty goals, necessary financial arrangements, cutting edge technology framework and sustained capacity enhancement framework are proposed, with the aim of supporting climate action by developing countries "and the most vulnerable countries" in tandem "with their own national objectives". The Paris Climate Change Agreement "also provides for enhanced transparency of action and support through a more robust transparency framework". It requires all the state parties to put forward their best efforts through "nationally determined contributions" and to ensure that these efforts are strengthened in the future. All Parties are required to report regularly on their emissions and efforts being made to implement the Agreement. The Paris Agreement which builds on the UNFCCC has assembled all the countries of the world "into a common cause to undertake ambitious efforts to combat climate change and adapt to its effects, with enhanced support to assist developing countries to do so". The Paris Agreement entered into force on November 4, 2016, thirty days after the date on which at least 55 state Parties to the UNFCCC accounting in total for at least an estimated $55 \%$ of the total global greenhouse gas emissions have deposited their instruments of ratification, acceptance, approval or accession with the Depository.

\subsection{Key Aspects of the Paris Climate Change Agreement}

The Paris Climate Change Agreement aims to strengthen the global response to the threat of climate change, in the context of sustainable development and efforts to eradicate poverty. It makes it incumbent on all state parties to contribute to climate change mitigation and adaptation. Countries are required for the first time, to develop plans on how to contribute to climate change mitigation and to communicate their "nationally determined contributions" to the Secretariat of the Convention. The Paris Agreement sets a global average temperature of well below 2 degrees Celsius above pre-industrial levels, recognizing that this would significantly reduce the risks and impacts of climate change.

It has been argued that the Paris Agreement's emphasis is on processes rather than on defined mitigation goals. The Paris Agreement did not set country specific targets as the Kyoto Protocol did. It rather relies on voluntary mitigation contributions and a series of processes in order to achieve collective and individual results in meeting the mitigation contributions. The Paris Agreement will be implemented to reflect equity and principle of common but differentiated responsibilities and respective capabilities, in the light of different national circumstances. This provision raises the issue of how to get developing countries to participate in low stabilization target. This article argues that the initially communicated Nationally Determined Contributions (NDC) fall short of the required expectation. A lot more is needed as this is the only way "to achieving the purpose of this Agreement as set out in Article 2". On the whole, the Paris Agreement contains: national action which parties must take "so as to achieve a balance between anthropogenic emissions by sources and removals by sinks of greenhouse gases in the second half of this century". The Paris Agreement provides that Parties should take action to conserve and enhance the preservation and protection of forests and other lands. Article 5 
states the importance of forests in the efforts to tackle climate change as "shrinking of forests contributes to global warming, and growing ones can counter it". The Paris Agreement failed however to create carbon markets, but encouraged Parties to support existing frameworks for Reducing Deforestation and Forest Degradation - REDD +.

Article 6 of the Paris Agreement covers a number of issues: cooperative approaches; transfers of mitigation outcomes; mechanism to contribute to mitigation and support sustainable development; and framework for non-market approaches. The Paris Agreement provides for "enhanced transparency framework for action and support". This provision contained in Article 13 has been argued by Martini to be "the backbone of the Paris Agreement".

According to Martini:

To have a shot at securing that future, it is essential that the implementation of a Transparency Mechanism under Article 13 of the Paris Agreement be developed in a robust manner. Capacity in carbon accounting must be strengthened in the developing world in order to effectively implement Article 13. Transparency is the backbone of the Paris Agreement.

The Paris Agreement provides for Conference of the Parties to ensure that the Agreement "is on track". The C.O.P. is to take stock of the implementation of the Agreement every five years. Other key provisions of the Paris Agreement are: global goal on adaptation; addressing loss and damage associated with the adverse effects of climate change; support for developing countries; the technology mechanism for technology transfer; capacity building; climate change education, training, public awareness, transparency framework for action and support; mechanism to facilitate implementation and promote compliance with the provisions; the Conference of the Parties as the supreme body of the Convention; Secretariat; Subsidiary Bodies; other institutional arrangements; agreement openness for signature; agreement's entry into force; provisions on the adoption of amendments to the Convention; annexes to the Agreement; settlement of dispute; rights to vote; depository of the agreement; no reservations to the agreement; withdrawal from the agreement; and deposition of the original of agreement.

The Paris Climate Change Agreement allows an established system which permits states parties to define NDCs without jeopardizing the overall goal of the UNFCCC and the Paris Agreement, at the same time not compromising their own ability. It is desired that with committed transparency and dedicated all-inclusive target, state parties are expected to put in place purposeful national plans that will implement the objectives of the Agreement. Events, have nevertheless, shown that state parties nationally determined contributions is a far cry from the intendment of the Paris Agreement, thus the Paris Agreement has been described as "a shell without sufficient action and support, unable to address the collective action problem of climate change". The partnership working of state parties to the Paris Agreement has no doubt engendered a lot of mutual trust and eagerness among the international comity of nations to tackle the causes of climate change. This article argues that in order to achieve enviable NDCs, there is compelling need to employ the use of cutting-edge technologies to further the overall 
objective of the Paris Agreement.

\section{Implementing the Paris Climate Change Agreement}

Glaser has stated that to make for a successful implementation of the Paris Climate Change Agreement, the Ad HOC Working Group on the Paris Agreement (APA), must adopt "rules, guidelines and processes" that "make a real change". To translate this "real change" into action, the Ad Hoc Working Group on the Paris Agreement (APA) must be geared towards effective implementation on "mitigation, adaptation, technology transfer, capacity building and finance".

The Paris Climate Change Agreement as discussed earlier, contain commitments for state parties to ensure that their greenhouse-gas emissions are put in the minimum that will not impact negatively on global warming. In effect state parties are enjoined to promote "innovative low-carbon solutions". State parties have great role to play in the implementation of the Paris Climate Change Agreement. Implementing the Paris Agreement requires that all the state parties get actively involved in steering their climate change commitments into operation; attaining the contemplated economic and social multiple benefits of climate policy; and putting in motion policies that will ensure low-carbon emissions, and climate-sturdy future.

Each state party to the Paris Climate Change Agreement must adopt policies and approaches best suited to their own environment. This article argues that the primary means to achieving and implementing the Paris Agreement is for state parties to domestic the UNFCCC into their national laws and incorporate the provisions of the Paris Agreement into such domestic laws. National targets must be set and pursued with political will and tacit governance; deep-rooted mitigation strategies; integrated adaptation planning; climate finance frameworks; measurement, reporting and verification (MRV) system. Political will and tacit governance is necessary in maintaining the thrust triggered during the preconceived Intended Nationally Determined Contributions (INDCs) process. There must be the political will that "places climate action in the context of national development priorities...". Tacit governance must ensure "accountability across the diverse actors responsible for taking forward implementation-national, sub-national, municipal, public and private". State parties to the Paris Agreement must put in place institutional arrangements that will be saddled with the functional responsibility of implementing the Paris Agreement and balancing the role of environment agencies and bringing them into the execution of policies and actions. All these are what Dodwell, has described as the five essential pillars of implementation which will maximize the chance of turning commitment and action into what countries, and the planet, really want-achievement of their climate goals. According to Dodwell, COP 21 marked the first time that the global community has made a legally binding declaration of intent to transition to a low-carbon economy.

In his writing, Sachs argues that implementing the Paris Climate Change Agreement is one of the central goals of the United Nations and States Parties. For Sachs, the human-induced climate change remains a global problem in its causes, consequences, and solutions, and this "can only be solved in the 
UN multilateral context".

It is pertinent to mention the 2016 United Nations Climate Change Conference, which incorporated the twenty-second Conference of the Parties (COP 22), the twelfth meeting of the parties for the Kyoto Protocol (CMP 12), and the first meeting of the parties for the Paris Agreement (CMA 1). The COP 22 discussed on the implementation plans for tackling climate change and to "[demonstrate] to the world that the implementation of the Paris Agreement is underway".

The outcome of COP 22 in Marrakech included the adoption of 35 decisions, pertaining mostly to the implementation of the Paris Agreement, which set 2018 deadline for developing a rulebook for the implementation of the Agreement, based on transparency, and accountability. The state parties agreed that the Adaptation Fund established in 2001 will serve the Paris Agreement. A five-year work plan for the Warsaw International Mechanism for Loss and Damage was endorsed. The state parties further endorsed the Marrakech Action Proclamation that reaffirmed their commitment to the implementation of the Paris Agreement. The state parties to COP 22 established the Marrakech Partnership for Global Climate Action, a platform that facilitates the involvement of non-state actors in pre-2020 climate action. A group which was not part of the formal negotiations, the "Climate Vulnerable Forum" declared their intention to switch to $100 \%$ renewable energy between 2030 and 2050 .

According to Erbach, there were fears concerning "engagement by the U.S.A." the world's second-largest GHG emitter. U.S. was seen as very important to the successful conclusion of the Paris Climate Change Agreement during the final negotiations in 2015. The U.S. in its Nationally Determined Contributions (NDC) commits to a reduction of its emissions by 26-28 percent below 2005 levels by 2025. Obama administration had presented a mid-century strategy for deep de-carbonization, which stated the pathways to reduce net GHG emissions by 2050 to one-fifth of 2005 levels.

\section{Where Does Africa Fit in?}

Climate change constitute notable danger to the sustainable economic, social and environmental growth in Africa as shown in the Fifth Assessment Report of the Intergovernmental Panel on Climate Change which detailed strong facts that global warming in Africa is not only a reality but has notoriously increased over the years, thus impacting negatively on the health, livelihoods and food security of people in Africa. This situation has caused health and economic problems for Africa lending to food insecurity, water scarcity, spread of weather-sensitive diseases, reduced agricultural yields and livestock productivity and terrorist activities due to displacement of people from their homes and agricultural farmlands. Thus, left with no option and bereft of any other means of livelihood are forced to join the terrorist groups emerging in the continent. Severe weather events, such as floods, droughts and health waves have become incessant in Africa and agricultural yields have continued to decline across sub-Saharan Africa as failed crop seasons persist.

It is evident that Africa has been extremely affected by the effects of climate change, notwithstanding that the continent contributes the minutest to global emission rates. Africa is in the throes of serious 
environmental challenges and the issues confronting the continent include: loss of biodiversity; rising sea levels; depletion of fish stocks; drought; deforestation; soil erosion; desertification and air pollution. All these have resulted in inadequate infrastructure, population pressures, chronic poverty, conflicts, political instability, terrorism and outbreak of diseases. In his writing, Binswanger-Mkhize has stated that for Africa, "climate change will provide both challenges and opportunities and [African] countries need to strengthen their general capacities to deal with stresses and weather shocks in line with general agricultural development priorities".

A prediction of future climate conditions and impacts in Africa shows that by 2080, an increase of 5 to 8 per cent of arid and semi-arid land in Africa is projected under a range of climate "scenarios". Further, due to climate change, it is most likely that 75 percent of African countries will be at the risk of extreme hunger. However, Africa has not gone to sleep, but has continued to key into the global efforts to address these challenges and impact of climate change on the continent. The continent is now committedly encouraging economic development that is in tandem with structural industrial changes aimed at reducing emissions. This commitment resulted in the Decision on the Coordination of the Committee of African Heads of State and Government on Climate Change (CAHOSCC) and Africa's Reparation for COP 19/CMP9.

This article argues that climate change remain one of the greatest challenges facing Africa nay the world today. In response to climate change governance, the international comity of nations established the UNFCCC with the mandate of seeking effective ways of tackling the climate change challenges at international level. Africa participated in the UNFCCC negotiations, though not favourably protected, until recently when the continent has stepped up its efforts in having an African Common Position for each session of the global climate change conferences. Prior to the COP 21 in Paris, the Climate for Development in Africa Programme held a three-day expert group meeting which inter alia, brainstormed the various aspects of climate change negotiations and its values to Africa. It discussed the advantages and disadvantages of the intended NDC to Africa; adaptation; loss and damage; technology transfer; climate finance and capacity development. The aim was to present a common stand at COP21 since climate change has become of major concern to Africa.

The Paris Climate Change Agreement is very significant for the African continent, because of its severe susceptibility to the impact of climate change. It is believed that the Agreement will help Africa to access windows and opportunities of funding and technology to tackle climate change, develop renewable energy resources and chart a new map to attain a sustainable future without compromising efforts to adjust to the influence of climate change. Forty-seven African nations signed the Paris Agreement on April 22, 2016, and nine deposited their articles for ratification of the Paris Agreement on climate change and seven of the African countries have ratified. It is therefore, very clear, that African countries have taken a concrete step in cementing their commitment to a climate change "development path, and helping the world draw closer to making the Agreement a global reality". This article argues that the Paris Climate Change Agreement is a "one size fits all" that does not address in 
practical terms the continued underdevelopment and acute climate "vulnerability" of the continent. However, this situation has not dampened the spirit of African countries as they continue to mount up efforts to place climate action in their regional and national development plans and policies. This is a very positive "signal of hope for the success of the Agreement".

With a cohesive African front, the Paris Agreement "could spell real action for Africa" in achieving "climate-resilient and low-carbon development" through NDCs. This could only be translated into "real change" with funding and technology support from the developed countries which control the climate change finance apparatus.

Richard Munang and Robert Mgendi have written that according to the former UN Secretary-General, "Africa's development and climate change experts are confident that the historic Paris Agreement on Climate Change... will be a win for the continent". Where Africa fits in has been described as "the sweet pot". This "sweet pot" represents the funding arrangements. The Paris Agreement and the supporting Decision contain provisions on finance and the introduction of USD100 billion annually by 2020 on the level of climate finance. It is through this funding mechanism that developed countries shall provide financial resources to assist developing countries like Africa with respect to mitigation and adaptation in continuation of their existing obligations under the Convention. The USD 100 billion climate finance will be scaled-up further in post-2025. The African negotiators had pressed for funding to be balanced between mitigation and adaptation initiatives as very important in achieving of sustainable development co-benefits. They succeeded in this, hence the content of Article 9 of Paris Agreement. The UN Environment Programme (UNEP) has published a Report which assesses a range of possible options for closing the adaptation finance gap on the continent. According to the report to tackle the "steep and rapid" increase in adaptation, funding from developed countries is needed to close the continent's adaptation funding gap, with African countries expected to raise US\$3 billion per year by 2020. This is not good news for Africa, a continent that bears the brunt of developed countries global emissions that continues to cause climate impacts adaptation costs and damage for Africa. Paris Agreement enjoins each state party to prepare, communicate and maintain successive nationally determined contributions (NDCs) that it intends to achieve. The transparency framework in the Paris Agreement, reiterated a clear obligation for financing information to be communicated every two years. This article argues that given the fact that African continent bears most of the impact of global emissions from developed countries; the content of the Paris Agreement in respect of adaptation financing mechanism represents a well-articulated provision. The aim remains for African nations to maximize the adaptation and mitigation windows opened by the Paris Agreement in order for the continent to attain "sustainable industrial development with minimal to zero emissions". The Paris Agreement promotes several initiatives in the area of technical and investment framework to support Africa's commitment at reducing carbon dioxide emissions. The Paris Agreement reinvigorated the resolve of Africa to face climate change, and to continue to adapt and mitigate its impacts on the continent. 
The Paris Climate Change Agreement provides opportunity for Africa to maximize the benefits of agricultural productivity through "ecosystem-based adaptation-driven approaches". The Paris Agreement promotes "a country-driven process to achieve" these goals. Through action on adaptation, Africa can achieve the Agreements aim of "strengthen[ing] the global response to the threat of climate change, "in the context of sustainable development and efforts to eradicate poverty". The Paris Agreement approach to adaptation and loss and damage is very encouraging and gladly enough, Africa has keyed into it. The Paris Agreement generally is a success for Africa but it still stands to be seen how these laudable provisions that are favourable to Africa will be translated into action. The Agreement is barely 16 months old, it is therefore too early to conclude on its gains in respect of Africa. The Paris Agreement remain viable platform for Africa to respond to climate change impact. This article briefly mentions the Transparency Mechanism contained in the Paris Agreement which has been described as "the backbone of the Paris Agreement" and "the Paris Agreement's key to success depends on hammering out the details to build a robust Transparency Mechanism". Transparency is specifically provided for in Article 13 of the Paris Agreement which articulates an "enhanced transparency framework for action and support" which "established harmonized monitoring, reporting, and verification (MRV) requirements". By this, the developed and developing nations are required to report every two years on their mitigation effort, and all parties will be subject to both technical and peer-review. An effective transparency mechanism will assist not only state parties of the developed countries but African countries to implement accurate and precise Measurement, Reporting and Verification (MRV) of greenhouse gas emissions.

\section{Case Studies of Some African Countries That Have Signed and Ratified the Paris Agreement}

As of 22 March 2017, 194 parties have signed the Paris Agreement, 144 parties ratified. When a country signs the Paris Agreement, it is obliged to refrain from acts that would negative its overall goal and objective. By ratification, the country signifies its intent to be legally bound to the provisions of the Agreements at the international level. This article in this section takes a brief look at some case studies of African countries that have signed and ratified the Paris Agreement and how they are benefitting or losing because of the Agreement, with particular reference to climate change impact and adaptation in Africa. We shall examine seven of the African countries which have ratified and which are pilots under the USD 8.3 billion Climate Investment Funds (CIF), programs which link their climate actions to their national development plans and policies. The seven CIF African countries are: Cameroon, Ghana, Madagascar, Mali, Morocco, Niger and Uganda. These countries are to base their climate decisions on their submitted NDCs, detailing their plans to limit greenhouse gas emissions in line with the Paris Agreement's overall goals "for a climate-safe future". These countries receive support from the African Development Bank (AfDB) to tackle "severe climate vulnerability".

Cameroon: The country has signed and ratified the Paris Agreement. It deposited its instrument of ratification with the United Nations on Friday, 29 July 2016, making it the 21st country to do so. By its 
submitted NDC, it committed to a target reduction of 32 per cent GHG by 2035 on the condition of financial support; preparing a CIF Forest Investment Program (FIP) IP; CIF-related sectors under its NDC include forests, energy and agriculture. Solely for the purpose of Article 21 of the Paris Agreement, Cameroon has communicated a total of 0.45 per cent of greenhouse gas emissions in its national communication. Cameroon intends to benefit from the Agreement in that it will help the country tackle the destructive effects of climate change on their environment. Cameroon by signing and ratifying the Paris Agreement has made climate change a priority. For Cameroon as other African countries, the Article 7 provision of the Paris Agreement which establishes "the global goal on adaptation" to "protect people, livelihoods and ecosystems" is unique and favours them. It also fulfills the desire of not only Cameroon, but African countries that funding will be directed towards adaptation since they are the burden bearers and victims of climate change.

Ghana: The country has signed and ratified the Paris Agreement, and communicated 0.09 per cent of greenhouse gas emission in its national communication through its submitted NDC which committed to a target of unconditional reduction by 2030 of 15 per cent greenhouse gas emissions and an additional 45 per cent which is conditional on funding support. Ghana has a CIF FIP IP with one approved project and is preparing an IP under the CIF program for Scaling Up Renewal Energy in Low Income Countries (SREP). It also provide for CIF-related sectors in its NDC to include energy, agriculture, forestry and land-use. Ghana's parliament has ratified the Paris Agreement on Climate Change to keep global emissions well below 2 degree Celsius to save the planet. Ghana has submitted its NDCs and outlined thematic areas for climate mitigation and adaptation, and is expected to be built into the country's Sustainable Development Goals (SDGs) and Shared Growth and Development Agenda and their 40 year National Development Plan. There are however, fears about Ghana's commitment to the Paris Agreement, as the country continues to build coal fired plants and more fossil fuel plants to generate electricity, thus, increasing the emission of greenhouse gas pollutants, which increase global warming. There is therefore a big question mark on reconciling Ghana's ratification of the Paris Agreement and its continued building of "new generator plants". It is nevertheless, believed that such fears are likely to be addressed by Ghana's implementation of its NDC on climate change.

Madagascar: The country submitted its new climate action plan to the UNFCCC ahead of the 2015 Paris Agreement. It signed the Paris Agreement on 22 April, 2016 and ratified it on 21 September, 2016 with entry into force on 4 November, 2016. By its submitted NDC, Madagascar, committed to a target reduction by 2030 of 29 per cent greenhouse gas emissions conditional on financial support. It also committed to preparing IPs under the CIF's SREP Program and its Pilot Program for Climate Resilience (PPCR); CIF-related sectors under its NDC include energy, agriculture, and land use, land use change and forestry. The country has to date, communicated a total of 0.08 per cent of greenhouse gas emissions in their national communication.

Madagascar remain among the top-ten countries of the world with important and extensive coastal zones, thus, signing and ratifying the Paris Agreement is very significant for the country in that it will 
help to mitigate climate change and reduce climate change vulnerability as well as promote adaptation measures.

Mali: On 22 April 2016 Mali signed the Paris Agreement and ratified it on 23 September, 2016. To date, Mali has through its national communication, communicated a total of 0.03 per cent of global emission of greenhouse gas emissions by 2030 for agriculture, 31 per cent for energy, and 21 per cent for forests conditional on financial support; has a CIF IP under CIF's SREP program with projects focusing on renewables, mini-grids, and private sector engagement; CIF-related sectors under tis NDC include agriculture, forests, energy, and land-use. More than 80 per cent of Mali's population of 17 million people depends on agriculture and it remains one of the world's poorest countries. Therefore, mitigating the impact of climate change by reducing carbon emissions is a pathway to "resolving its environmental problems". Adaptation, that is responding to the severe climate pattern, droughts and scarce rainfalls which occur in Mali becomes necessary and the Paris Agreement provides a way out. Global warming is everyday problem in Mali and it affects the citizens badly. It is a daily life issue for Malians, thus, the significant of the Paris Agreement speaks to the country.

Morocco: The first session of the Conference of the Parties serving as the Meeting of the Parties to the Paris Agreement (CMAI) took place in Marrakech, Morocco from 15-18 November 2016. This is significant for the country that signed the Agreement on 22 April 2016 and ratified on 21 September 2016, with entry into force on 4 November 2016. To date, the country has through its national communication, communicated to a total of 0.16 per cent of greenhouse gas emissions. It has through its submitted NDC committed to a target of unconditional reduction by 2030 of 17 per cent greenhouse gas emissions and an additional 42 per cent conditional on financial support. The country has a CIF IP under the Clan Technology Fund (CTF) through which it has developed several globally significant showcase projects; CIF-related sectors under tis NDC include energy.

Niger: The Paris Agreement was signed by Niger Republic on 22 April 2016, ratified on 21 September 2016 and entry into force on 4 November 2016 to date, the country has communicated a total of 0.04 per cent of greenhouse gas emissions through its national communication. Through its submitted NDC, it committed to a target of unconditional reduction by 2030 of 3.50 per cent greenhouse gas emissions and an additional 34.60 per cent conditional on financial support. It has an IP under the CIF PPCR program with approved projects in climate information and water resource management; $\mathrm{CIF}$-related sectors under its NDC include land-use, land-use change and forestry. The Paris Agreement empowers Niger to act to prevent average global temperatures rising above 2 degrees Celsius. The country will also reap the many opportunities that arise from "a necessary global transformation to clean and sustainable development".

Uganda: On April 222016 Uganda signed the Paris Agreement and ratified it on 21 September 2016 with entry into force on 4 November 2016. The country has through its submitted NDC, committed to a target of $77.3 \mathrm{MtCo} 2$ e per year by 2030. It has an IP under the CIF SREP program with projects to be developed in solar and geothermal energy; CIF-related sectors under its NDC include energy and Published by SCHOLINK INC. 
infrastructure.

In summary, African countries benefit from the climate change and adaptation, through financial support, capacity-building, technology transfer, adaptation and mitigation provisions contained in the Paris Agreement. The financing instruments are available to them to access and utilize to implement CIF-funded projects and programs.

\section{The Challenge for Africa}

Africa is bestride with several challenges that are likely to affect the implementation of the Paris Agreement in the continent. This article argues that the provisions on intended Nationally Determined Contributions (NDCs) which become legally binding as Nationally Determined Commitments, with the coming into force of the Paris Agreement need to be reviewed by African countries. This review is necessary in order to address challenges that are likely to affect the implementation of the Agreement. This is so, because apart from the fact that about 19 African countries have ratified the agreement, Africa account for only 1.06 per cent of global emissions. This situation of Africa binding itself legally to NDC is challenging. There are other challenges associated with the INDC submissions of several African countries. There are "vagueness in their mitigation ambitions and adaptation aspirations, lack of cost estimates for achieving their adaptation and mitigation goals, absence of clarity on sources of funding and absence of up to date national GHGs emission records".

Africa also faces the challenges of mitigation commitments that exceed current level of emissions and lack of coherence between some of the INDCs and national development plans and strategies. The ambitious emission targets set prior to the Paris Agreement is already becoming a challenge for some African countries. For the African country of Chad Republic, the country's climate envoy at the United Nations has stated the country's plans to slash its greenhouse gas emissions to 18 per cent as against the initial 71 per cent by 2030, the country had earlier on stated in 2015. Chad is an arid oil producing country which has long be devastated by internal conflicts and the challenge of funding or support is real, not just a mere rhetoric. Chad has argued that the country "was pressured into this ambitious contribution of [71 per cent greenhouse gas emissions cut by 2030] and it will not be able to deliver". According to Souleymane, "I personally think that the very ambitious INDC [climate plan] like ours is not achievable and it needs to be reviewed. We have been rushed by other countries, and we have elaborated a quick INDC, we did not gather all the data to reflect our national and achievable contribution, which normally [should] take into account sustainable development".

The challenges and fears faced by Chad is not peculiar to that country, but extends to other African countries. The African Group, a United Nations negotiating alliance with 54 member nations are likely to "seek permission to amend or revise their climate plans". This is so because most of them "are not happy with the target". The group has expressed reservations on the attitude of Western nations and the Climate finance mechanism. The funds released to assist African countries prepare their "intended nationally determined contributions" were hijacked by the consultants from the developed countries 
who were nominated by the donor countries to steer "a supposedly nationally-owned process". Nigeria, Tanzania and Ethiopia are among the African countries that are likely to pursue slashes of their "ambitious carbon reduction goals" due to the fact that they may have serious challenges meeting their commitments. According to Okereke, there is "a sense of skepticism and buyer's remorse from a number of African countries, who are asking: hang on, what have we committed to?" Okereke has expressed that:

The process through which many of these INDCs were written was seriously fraught with error, with minimal stakeholder consultation, data gathering and analysis... It is understandable that France wanted to get an agreement, but I fear the success in Paris may have come at the expense of African countries.

Okereke and Souleymane agrees "that the process leading to the development of the plans for African countries was not based on rigorous assessments, and was in some cases flawed". This article argues that despite all the climate change conferences, agreements and promises, "Africa's plight in the face of ever-increasing climate threats is one of the priorities" that the global community must address urgently. Climate change impacts have continued to devastate African countries causing negative rainfall patterns, weak harvests, increased immigration, conflicts, food scarcity, drying up of rivers, flooding and energy crisis. In spite of all these challenges, climate financing to assist the continent adapt to climate change impacts are not forthcoming as needed. It has become very clear that African countries committed to the Paris Agreement and INDCs without really having a plan as to how to meet those targets. This is a major challenge.

Despite these challenges, African countries believe that the Paris Agreement is worth the signing and ratification, that by and large it will help them weather climate change impacts. This article argues that as exciting as this may be, "there is [still] a widespread belief that support to help the continent prepare for erratic rains and the drought and famine that can result has not been forthcoming". This is true, because as at now, there is no common agreement on how adaptation is going to be funded.

Africa urgently needs funding to pursue its agricultural productivity agenda and "to develop further and polish NDCs in order to broaden their scope and plan on how to mainstream them in the development processes". Has Africa benefitted sufficiently from the Paris Agreement? The answer is in the negative. Africa requires more sincere and dedicated commitment from the developed nations. For the continent to abandon its old ways of doing business, a lot of funding is required, therefore, implementation of the Agreement still presents challenges for Africa. This article argues that the Paris Agreement in its present form and content does not fully represent the legitimate aspirations and expectations of the African countries.

\section{Conclusion}

Finance and investment are the major windows to achieving low-emissions in Africa. The developed nations are obligated to provide sufficient funding to finance climate action in Africa in order to attain 
the below 1.5 degree Celsius target above the pre-industrial levels. Developed country parties should also hasten to provide "predictable and sustainable support" in terms of technology and capacity building to achieve the adaptation and mitigation needs of the continent. The USD100 billion earmarked for climate financing in developing country parties, while a good start, should be increased. African countries should put in more transparency in managing the funds whenever they receive them in order to cultivate confidence in the donors that it is not going to be business-as-usual, where such funds are diverted in prosecuting internal conflicts, building private mansions and laundering into foreign bank accounts of government officials.

Donald Trump's anti-climate change stance in describing climate change as "a hoax", though very disturbing for African nations, cannot and will not be allowed to deter Africa's push and commitment towards sustainable climate action. Africa's response to climate change impacts need to begin from first appreciating the irreversible damage that it causes to the continent, then acquiring appropriate knowledge via critical climate information, strengthening policy decisions, rational policies and certainly pushing "beyond the boundaries of hope". Climate action in Africa should be seen as a collective project, where climate funding are channeled towards tackling the environmental challenges arising from loss and damage. The continent must also demonstrate political will that is needed to trigger off climate action and commit into "championing projects that demonstrate that a low carbon development pathway will make investment and business sense...". It is important that Africa pursues the content of the Paris Agreement. Industrialization and green growth should be done side by side, they should be both balanced for enduring sustainable development.

African countries must single out viable and sustainable projects, reform institutions with functional responsibility in implementing them and enhance capacity building to manage climate finance in line with the goals of the Paris Agreement. In moving forward, what were formerly addressed as INDCs and has become known as NDCs requires capacity building in the nature of carbon accountants. This means that African countries which are parties to the Paris Agreement without any expertise or experience in carbon accounting needs human capacity resources to be trained in technical expertise in this field. Capacity in carbon accounting must be strengthened in Africa in order to effectively implement the Agreement. The Measure and Report ( $M$ \& R) for Africa need immense strengthening if the Paris Agreement would be a success. Another "sweet in the pot" in the Paris Agreement for Africa is the doing away with the "one size fits all" model of international environmental policy in favour of more diversified, inclusive approach.

Africa is not alone in striving to achieve the overall goals of the Paris Agreement, it is a global and collective Agreement that aims to tackle carbon emission and temperature to well below $2^{\circ} \mathrm{C}$ above pre-industrial levels and at the same time strive to limit the temperature rise to $1.5^{\circ} \mathrm{C}$ above pre-industrial levels in this century. This is the whole message of the Paris Agreement and for Africa this ambitious climate action is only realizable through exploring modalities for achieving the adaptation goal, capacity building, technology transfer, building technical skills, the adequacy and 
effectiveness of climate funding and institutional strengthening for a purposive implementation.

\section{References}

Africa's 'Buyer's Remorse' over Paris Climate Deal. (2016). Climate Home.

Africa's Adaptation Gap Report 2: Bridging the Gap-Mobilizing Sources (2015, February).

African countries are members of non-Annex 1 countries. (March 30, 2017). Parties and Observers. Retrieved March 30, 2017, from http://unfccc.int/partiesandobservers/items/2704.php

African Development Bank Group. (2014). AFDB Convenes Lenders to Secure Kenya's Largest Private Sector Investment. Retrieved March 30, 2017, from http://www.afdb.org/en/blogs/a-race-against-time

African Development Bank Group. (2016). Climate Change in Africa: A Race Against Time. Retrieved March 30, 2017, from hppts://www.afdb.org

At COP 19. (2013, November). In Warsaw, Poland, the COP established the Warsaw International Mechanism for Loss and Damage associated with Climate Change Impacts (Loss and Damage Mechanism), to address loss and damage associated with impacts of climate change, including extreme events, and slow onset events, in developing countries that are particularly vulnerable to the adverse effects of climate change.

Bank Ki-moon. (n.d.).

Binswanger, H. P. (2009). Challenges and Opportunities for African Agriculture and Food Security: High Food Prices, Climate Change, Population Growth and HIV and AIDS. Expert Meeting on How to Feed the World in 2050. In Food and Agriculture Organization of the United Nations Economic and Social Development Department (p. 54).

Canada, Mexico, Germany and the U.S.A. laid out strategies for de-carbonizing their economies by 2050. (n.d.).

Chakravarty, S., \& Chikkatur, N. (2009). Sharing Global CO2 Emissions Reductions Among 1 Billion High Emitters. In Proceedings of the National Academy of Sciences (Early ed., pp. 1-5). https://doi.org/10.1073/pnas.0905232106

Change, United Nations Framework Conventions on Climate Marrakech Climate Change Conference. (2016). Retrieved from http://www.unfccc.int

Chin-Yee, S. (2016). Briefing: Africa and the Paris Climate Change Agreement. African Affairs (Oxford University Press). https://doi.org/10.1093/afraf/adw005

Climate Focus. (2015).

Climate Focus. (2015). The Paris Agreement: Summary. Climate Focus Client Brief on the Paris Agreement III. Retrieved March 31, 2017, from http://www.climatefocus.com/sites/default/files/20151228

Climate Investment Funds (CIF). (2008). As one of the largest fast-tracked climate financing instruments in the world. CIF provides USD 8.3 billion to developing countries as grants, 
concessional loans, risk mitigation instruments and equity. Five MDBs-The African Development Bank (AFDB); the Asian Development Bank (ADB); European Bank for Reconstruction and Development (EBRD); Inter-American Development Bank (IDB); and World Bank Group (WBG) implement CIF-funded projects and programs.

Climate Vulnerable Group at COP 22, a group of 48 developing countries. (n.d.).

Coordination mechanism of the Committee of African Heads of State on Climate Change (CAHOSCC). (2011). Taken during the 2011 Malabo Summit authorizing the Climate for Development in Africa (ClimDev-Africa) Programme, to organize and manage Africa's participation at all COP events.

Denton, F. (2015). Africa in the Post-2015 Climate Change Agreement. A Speech on the occasion of Africa Day event organised on 10th December 2014 at COP20 in Lima Peru.

Dodwell, C. (2016). Implementing the Paris Climate Agreement. In Ricardo Energy and Environment. Retrieved from http://www.eerocardo.com/cms/assets/international/COP21

Dorsouma, A. H. (2016). Is Green Climate Fund Fit for Purpose in Africa? Retrieved March 30, 2017, from http://www.afdb.org/en/blogs/a-race-against-time

du Plessis, A., \& Kotze, L. J. (2014). The Heat is On: Local Government and Climate Government in South Africa. Journal of African Law. https://doi.org/10.1017/s0021855314000047

Elasha, B. O. (2015). Africa's Climate Challenge. Retrieved April 2, 2017, from http://www.climate2020.org.uk

Erbach, G. (2016). Outcomes of COP 22 Climate Change Conference. Retrieved from http://www.epthinktank.eu

Erbach, G. (2016). The Paris Agreement: A New Framework for Global Climate Action' European Parliamentary Research Service EPRS.

Ethiopia ahead of the COP21 Paris Conference. (n.d.).

Ethiopia said 10.2 million people needed humanitarian assistance in 2016 at a cost of USD 1.4 billion, due to drought caused by climate impacts. (2016).

Fisher, A. (2009). (2009). Little Accord in Copenhagen. Retrieved from March 30, 2017, from http://www.aljazera.com/focus/climatesos/ 2009/219174523761297.html

Gatherer, D. (2014). The 2014 Ebola Virus Disease Outbreak in West Africa. Journal of General Virology, 95, 1619. https://doi.org/10.1099/vir.0.067199-0

generally, O. et al. (2015). Climate Change Impacts in Sub-Saharan African: From Physical Changes to their Social Repercussions. Regional Environmental Change, 15(8), 19.

Glaser, D. (2016). 4 key Steps To Implementing The Paris Agreement, British Columbia Council for International Cooperation. Retrieved April 1, 2017, from http://www.twitter.com/BCCIC

Hamid Abakar Souleymane, who also represents Chad at the UN's Climate Science Panel. (n.d.).

Handbook, A. (2016). Africa Urged to Address Challenges That May Affect Paris Agreement Implementation. Retrieved April 3, 2017, from http://www.uneca.org/stories/africa

In an effort to help those suffering in Mali and elsewhere in Africa, the French government has pledged 
2 billion Euros, that is USD 2.1 billion by 2020 for the development of sustainable energies in Africa. (n.d.).

IPCC. (2014). Climate Change 2014: Synthesis Report-The Fifth Assessment Report of the Inter-governmental Panel on Climate Change (AR 5).

Marrakech Action Proclamation for Our Climate and Sustainable Development. (n.d.).

Marrakech Partnership for Global Climate Action. (n.d.).

Martin, E. F. (2017). With a United African Front, the COP of Action Could Spell Real Action for Africa. Retrieved March 30, 2017 from http://www.afdb.org/en/blogs/a-race-against-time

Martini, C. (2016). Transparency: The Backbone of the Paris Agreement. Yale Center for Environmental Law and Policy, Yale University.

Martini, C. (2016). Transparency: The Backbone of the Paris Agreement. Yale Center for Environmental Law and Policy. Retrieved from http://www.envirocenter.yale.edu

Mcmanus, K. (2009). The Principle of Common but Differentiated Responsibility and the UNFCCC. Retrieved from http://www.climaticoanalysis.org

Munang, R., \& Mgendi, R. (2016). The Paris Climate Deal and Africa. Africa Renewal magazine. https://doi.org/10.18356/584afe1c-en

Okereke cites Nigeria's target of $45 \%$ GHG cuts with external support and $25 \%$ without as one of the more unrealistic government aspirations ahead of Paris. The country's electricity grid has a capacity of less than 5,000 megawatts, but its 173 million citizens need generation sources ten times that. Where is that cut going to come from? This is a country that needs to grow and is fossil fuel based. Nobody has given me any analysis. (n.d.).

Sachs, J. D. (2016). Implementing the Paris Climate Agreement-Achieving Deep De-carbonization in the Next Half-Century. Horizons Journal of International Relations and Sustainable Development, 2016(8).

Smith, B. (2016). Adapting the Paris Agreement. Standford Environmental Law Journal (SELJ). Retrieved from http://www.journals.laws.standford.edu

The Ad Hoc Working Group on the Paris Agreement (APA) is made up of all Parties that adopted the Parties Agreement. (n.d.).

The African Union Commission and UNEP. (n.d.). Have set up Ecosystem-Based Adaptation for Food Security Assembly (EBAFOSA) aimed at promoting agro-value chains through EBA-driven agricultural approach.

The Economist. (2015). Forests and Climate Change: Hope for the Trees. Paris.

The last session before the Conference was held in Benin. (2015).

The outcome of the U.S. presidential election has cast doubt over future U.S. commitment to climate action. President Donald Trump do not believe in climate change which he has severally described as 'hoax.' He has also declared that he intends to reconsider U.S. participation in the Paris Agreement. However, about 300 U.S. companies have written President Trump affirming 
their resolve for low-carbon energy and support for the implementation of the Paris Agreement. (n.d.).

The Paris Agreement Summary' (PDF). Climate-Focus. (2015).

The Venice. (2013-2014). Based NGO records that USD 11 billion was spent on sub-Saharan Africa between 2013-2014, compared to USD 15 billion in South Asia and USD 26 billion in Latin America. The UN-Backed Green Climate Fund supposed to drive support for Africa to meet the Paris Agreement's ambitions in Africa has received only USD 10 billion from the rich nations.

United Nations Framework Convention on Climate Change. (2014). The Paris Agreement. Retrieved March 31, 2017, from http://www.unfccc.int/paris_agreement/items/9485.php 